\title{
CASE NOTES
}

Edited By Justin GAu

Barrister, Deputy Chancellor of the Diocese of Lincoln

Ruth ARLOW

Barrister, Deputy Chancellor of the Dioceses of Chichester and Norwich

And Will Adam

Rector of Girton, Ely Diocesan Ecumenical Officer

\section{Trustees of the Roman Catholic Church v Ellis}

Court of Appeal of the Supreme Court of New South Wales, May 2007

Sexual abuse - vicarious liability - Archbishop as corporation sole

In proceedings commenced in the New South Wales Supreme Court in 2004, the plaintiff alleged that, while he was a young altar server, he was sexually abused by an assistant priest in a Roman Catholic church between 1974 and 1979. He sued three defendants: the Cardinal Archbishop of Sydney for and on behalf of the Roman Catholic Church in the Archdiocese of Sydney; the Trustees of the Roman Catholic Church for the Archdiocese of Sydney; and the alleged abuser.

The priest had been appointed by the then archbishop (in office between 1971 and 1983), acting in consultation with the Archdiocesan Council, being a separate body from the Trustees. The current archbishop was appointed in 2001 and had no relevant connection with the Sydney Archdiocese prior to that time. The proceedings were framed in negligence and assault. The priest died in 2004 and the plaintiff indicated that he did not intend to continue the proceedings against his estate.

Liability against the archbishop was alleged under various grounds in tort and by way of breach of fiduciary duty in equity both directly and vicariously. Liability against the Trustees was alleged under various grounds in tort both directly and vicariously. The plaintiff alleged that the archbishop and the Trustees were liable directly or in a representative capacity (representing the unincorporated association known as the Catholic Archdiocese of Sydney) for the wrongdoing of the priest. The plaintiff also invoked the legal concepts of a corporation sole as the basis of obtaining damages or compensation against the archbishop, who, together with the Trustees, denied liability and alleged that they were not the proper defendants.

The plaintiff turned 18 in 1979 and his claims in tort became statute-barred in 1985. The plaintiff sought an extension of time. The evidence was that the 
diocesan bishop had very extensive control over the appointment, removal and day-to-day activities of an assistant parish priest. The current membership of the Archdiocese was estimated to be in excess of 580,000 persons. The functions of the Trustees were to hold, control and dispose of church property. They had no role in the appointment, management and removal of priests. Patten AJ, at first instance, held that there was no basis upon which the cause of action in tort could be maintained against the archbishop either personally or as a representative of the members of the Roman Catholic Church in the Archdiocese of Sydney. As against the Trustees, he held that there was an arguable case that the Trustees were liable in tort because the Trustees constituted the entity that the Roman Catholic Church in the Archdiocese of Sydney adopted as its permanent corporate entity. An order was made extending the limitation period against the Trustees, but the application as against the archbishop was dismissed. The New South Wales Court of Appeal upheld the appeal of the Trustees and dismissed the cross-appeal of the plaintiff.

As to the alleged vicarious liability of the archbishop and the Trustees, Mason P (at paragraph 54) held that the relationship between an assistant parish priest and the 'members' as a whole is too slender and diffuse to establish agency in contract or vicarious liability in tort. There was no evidence that the priest was engaged or employed by either the archbishop or the Trustees, let alone by all of the members of the Church in the Archdiocese, during the relevant years. Further, the requirements for the making of a representative order under the court rules had not been satisfied.

As to the alleged direct liability of the Trustees, Mason P (at paragraphs 140 and 141) held that there was no evidence that the Trustees were involved in the pastoral activities of appointing, managing and disciplining priests at the time of the alleged torts. Mason P (at paragraphs 145-148) distinguished on the basis of different statutory functions the judgment of the Supreme Court of Canada in John Doe v Bennett [2004] 1 SCR 436, in which it was held that the Roman Catholic Episcopal Corporation of St George's could be sued for the sexual assaults of a priest.

As to the alleged direct liability of the archbishop for the acts of his predecessor on the basis that he is a corporation sole liable, Mason P (at paragraphs 152-181), after considering the concept of a corporation sole under the common law and in United States law, and the history of the Roman Catholic Church in Australia, held that he is not a corporation sole and cannot be made liable for the alleged torts of his deceased predecessor as archbishop. He held (at paragraphs 191-197) that the archbishop and the Trustees were not estopped from denying that they are the proper defendants. A draft deed of release prepared during ultimately fruitless settlement discussions contained no implied representation as to the parties that the plaintiff could sue if he 
rejected the settlement offered. Further, there was no evidence of detrimental reliance by the plaintiff upon the alleged representations.

Summary provided by Garth Blake SC. The judgment is available at <http://www. austlii.edu.au/au/cases/nsw/NSWCA/2007/117.html>. Leave to appeal has been refused by the High Court of Australia.

doi:10.1017/So956618Xo8001543

\section{McClintock v Department for Constitutional Affairs}

Employment Appeal Tribunal: Elias J, October 2007

Same-sex adoption - judicial oath - discrimination - religious objection

The appellant was a Justice of the Peace, who requested that he be relieved of his duty to officiate in cases where there was a possibility of directing the placement of children with same-sex couples, on the basis that the merits of such placements had been inadequately researched and as such were 'social experiments'. That request was refused by the respondent, as a result of which the appellant resigned from his position on the family panel. The appellant brought proceedings alleging that, as a result of the refusal, he had been forced to resign, such refusal amounting to:

i. Direct discrimination;

ii. Indirect discrimination; and/or

iii. Harassment

in breach of the Employment Equality (Religion or Belief) Regulations 2003. The appellant stated that he could not in conscience, and compatibly with his philosophical and religious beliefs, agree to place children with same-sex couples. He argued that the respondent's refusal to accommodate his belief infringed his Article 9 right to freedom of conscience, religion and belief. The Employment Tribunal rejected the appellant's claims. In refusing the appeal, the Employment Appeal Tribunal found that the objections raised by the appellant at the time of his request (namely that there was currently inadequate evidence to support the suggestion that single-sex parents could be in a child's best interests) did not constitute a religious or similar philosophical belief within the terms of the 2003 regulations. The EAT further found that, in any event, the respondent had made out the defence of justification in that it was fully justified in insisting that Justices of the Peace apply the law of the land in accordance with their judicial oath. [RA] 